DOI

\title{
ВИВЧЕННЯ ЗАЛЕЖНОСТІ ЗВ'ЯЗКУ „СТРУКТУРА - ПРОТИЗАПАЛЬНА ДІЯ» ТА «СТРУКТУРА - АНАЛЬГЕТИЧНА ДІЯ» СЕРЕД ПОХІДНИХ АМІДІВ МАЛОНОВОЇ ТА ЩАВЛЕВОї КИСЛОТ
}

\author{
(c) Н. Г. Вахніна \\ Національний фрармацевтичний університет, Харків
}

Резюме: стаття присвячена дослідженню протизапальної та анальгетичної дії 43 нових похідних малонової та щавлевої кислот та дослідженню взаємозв'язку «структура - фрармакологічна активність».

Скринінгові дослідження проведені на моделях гострого карагенінового набряку та «оцтовокислих судом» у щурів. Для нових сполук встановлені закономірності антиексудативної та протибольової активності від хімічної структури молекули. Встановлено, що із 43 досліджуваних сполук максимальну протизапальну та анальгетичну дію чинить сполука під лабораторним шифром 16 (ди-(2,4-диметил) анілід малонової кислоти.

Ключові слова: похідні малонової кислоти, похідні щавлевої кислоти, протизапальна дія, анальгетична дія.

Вступ. Нестероїдні протизапальні засоби (НП3з) посідають одну із найбільш важливих позицій у клінічній практиці. Основними показаннями їх призначення є запальні процеси різного ґенезу, біль, лихоманка, захворювання сполучної тканини.

На сьогодні НПЗ3 - один 3 найбільш ефективних лікарських препаратів для лікування захворювань опорно-рухового апарату. Кожного дня у всьому світі більше 30 млн людей приймають НПЗ3, причому 2/3 пацієнтів - безрецептурні НПЗ3. Головними вимогами до препаратів із протизапальною та анальгетичною дією $є$ ефективність та безпечність у застосуванні $[5,6]$.

Проте всі існуючі на фрармацевтичному ринку НПЗ3 мають обмеження до застосування, протипоказання та досить високий ризик розвитку небажаних реакцій. Останні зустрічаються у 25 \% випадків приймання НП33, а у 5 \% хворих індукують розвиток серйозних ускладнень [4, 7].

Вченими НФаУ, під керівництвом профр. П. А. Безуглого, було синтезовано нову комбінаторну бібліотеку похідних амідів малонової та щавлевої кислот із прогнозованою протизапальною та анальгетичною дією.

Мета роботи - вивчення залежності зв'язків «структура - протизапальна дія» та «структура - анальгетична дія» серед 43 похідних амідів малонової та щавлевої кислот.

Методи дослідження. Дослідження проведені на тваринах, яких утримували у віварію ЦНДЛ НФаУ на звичайному харчовому та водному раціоні. Досліди здійснювали згідно 3 «Правилами проведення робіт з використанням експериментальних тварин» (Страсбург,18.03.86) [2].
Об'єктами досліджень обрані нові хімічні сполуки, які синтезовані вченими НфаУ під керівництвом проср. П. А. Безуглого. Хімічна структура досліджуваних речовин наведена у таблиці 1.

Структура досліджуваних сполук:

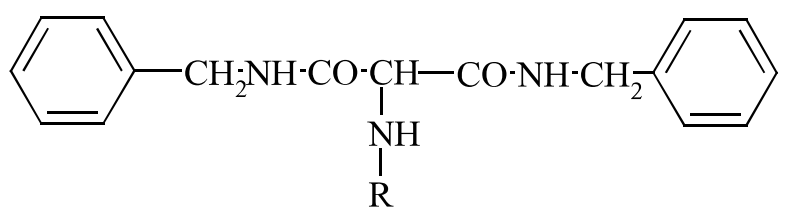

похідні дибензиламіду феніламіномалонової кислоти (сполуки 1-13)<smiles>[R]c1ccc(NC(=O)C([R])C(=O)Nc2ccc([R1])cc2)cc1</smiles>

похідні дизаміщених дианілідів малонової кислоти (сполуки 14-26)

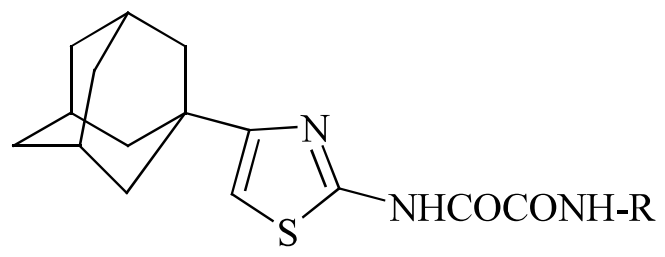

похідні 4-(адамантил-1)-тіазоліл-2-амідів щавлевої кислоти (сполуки 27-30)

ISSN 2312-0967. Pharmaceutical review. 2015. № 4 
Синтез біологічно активних сполук Synthesis of biologically active compounds

Таблиця 1. Хімічна структура досліджуваних сполук

\begin{tabular}{|c|l|l|}
\hline $\begin{array}{c}\text { Сполука, } \\
\text { лабораторний } \\
\text { шифрр }\end{array}$ & $\mathrm{R}$ \\
\hline 1 & 2-НОOC-C6H4 & \\
\hline 2 & 2-НО-С6H4 & \\
\hline 3 & 2-Н3СООС-С6H4 & \\
\hline
\end{tabular}

похідні 4-(адамантил-1)-тіазоліл-2-амідів малонової кислоти (сполуки 31-36)<smiles>[R]NC(=O)Nc1ccc([R])cc1</smiles>

похідні дизаміщених феніламідів щавлевої кислоти (сполуки 37-43)

У роботі використовували відомі експериментальні моделі. Протизапальну дію досліджували за умов відтворення гострого карагенінового набряку стопи у щурів; анальгетичну активність - на моделі «оцтовокислих судоми» у щурів [1].

Досліджувані сполуки вводили експериментальним тваринам внутрішньоочеревинно у дозі $1 / 20$ ЛД $_{50}$.

Оскільки досліджували досить велику кількість нових сполук, це не дозволило провести експеримент за 1 добу, для кожних 5 субстанцій під час проведення досліду вводили нову групу контрольної патології.

Препарат порівняння «Вольтарен» (диклофенак натрію) вводили щурам внутрішньошлунково одноразово у дозі 8 мг/кг, рекомендованій для проведення доклінічних досліджень, препарат порівняння «Анальгін» (метамізол натрію) вводили щурам внутрішньошлунково одноразово у дозі 50 мг/кг.

Отримані експериментальні дані обробляли статистично з використанням $\mathrm{t}$ - критерію Стьюдента [2].

Результати й обговорення. Результати дослідження можливої протизапальної дії нових сполук наведені у таблиці 2.

Гостре карагенінове запалення характеризується розвитком потужної запальної реакції, яка на 4-ту годину експерименту верифікується значним набряком стопи у експериментальних тварин (табл. 2). Діапазон збільшення об'єму лапки коливається від 1,28 до 1,68 умовних одиниць набряку.

Встановлено, що більшість сполук виявляє досить слабку антиексудативну дію.

Вірогідна протизапальна активність, яка статистично значуще відрізняється від показників групи контрольної патології, виявлена у трьох сполук під лабораторними шифрами № 8, № 16 та № 34 та складає 32,7, 60,4 та 28,8 \% відповідно.

Серед досліджуваних похідних 4-(адамантил-1)тіазоліл-2-аміду щавлевої кислоти сполуки № 31-36 максимальну антиексудативну дію проявляють молекули під шифром № 35 (25,8 \%) та № 34 (28,8 \%), причому остання має статистично значущі відмінності із групою контрольної патології.

ISSN 2312-0967. Фармацевтичний часопис. 2015. № 4 
Синтез біологічно активних сполук Synthesis of biologically active compounds

Таблиця 2. Протизапальна активність 43 похідних амідів малонової та щавлевої кислоти у щурів

\begin{tabular}{|c|c|c|c|}
\hline Група, шифр сполуки & Доза, мг/кг & 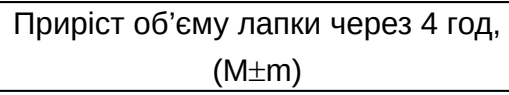 & $\begin{array}{c}\text { Протизапальна } \\
\text { активність, \% }\end{array}$ \\
\hline 1 & 2 & 3 & 4 \\
\hline Сполука № 1 & 8,1 & $1,66 \pm 0,16^{\#}$ & 1,2 \\
\hline Сполука № 2 & 9,4 & $1,67 \pm 0,14^{\#}$ & 0,6 \\
\hline Сполука № 3 & 6,9 & $1,42 \pm 0,11^{\#}$ & 15,5 \\
\hline Сполука № 4 & 10,6 & $1,44 \pm 0,12^{\#}$ & 14,3 \\
\hline Сполука № 5 & 12,9 & $1,36 \pm 0,08$ \# & 19,0 \\
\hline Контрольна патологія & - & $1,68 \pm 0,21$ \# & - \\
\hline Сполука № 6 & 15,6 & $1,14 \pm 0,06^{\#}$ & 20,3 \\
\hline Сполука № 7 & 8,9 & $1,02 \pm 0,02$ \# & 28,7 \\
\hline Сполука № 8 & 18,1 & $0,96 \pm 0,05^{*}$ & 32,7 \\
\hline Сполука № 9 & 21,3 & $1,11 \pm 0,07^{\#}$ & 22,4 \\
\hline Сполука № 10 & 26,3 & $1,32 \pm 0,13^{\#}$ & 7,7 \\
\hline Контрольна патологія & - & $1,43 \pm 0,17^{\#}$ & - \\
\hline Сполука № 11 & 26,8 & $1,47 \pm 0,18^{\#}$ & 4,5 \\
\hline Сполука № 12 & 81,2 & $1,51 \pm 0,09 \#$ & 1,9 \\
\hline Сполука № 13 & 66,3 & $1,44 \pm 0,13^{\#}$ & 6,5 \\
\hline Сполука № 14 & 16,3 & $1,26 \pm 0,02^{\#}$ & 18,2 \\
\hline Сполука № 15 & 15,8 & $1,06 \pm 0,05^{\#}$ & 31,2 \\
\hline Контрольна патологія & - & $1,54 \pm 0,19$ \# & - \\
\hline Сполука № 16 & 14,6 & $0,63 \pm 0,11^{*}$ & 60,4 \\
\hline Сполука № 17 & 16,8 & $1,39 \pm 0,22$ \# & 12,6 \\
\hline Сполука № 18 & 20,0 & $1,34 \pm 0,26$ \# & 15,7 \\
\hline Сполука № 19 & 17,0 & $1,52 \pm 0,13^{\#}$ & 4,4 \\
\hline Сполука № 20 & 17,3 & $1,51 \pm 0,07$ \# & 5,0 \\
\hline Контрольна патологія & - & $1,59 \pm 0,24$ \# & - \\
\hline Сполука № 21 & 13,3 & $1,44 \pm 0,06$ \# & 2,7 \\
\hline Сполука № 22 & 14,8 & $1,38 \pm 0,17^{\#}$ & 6,8 \\
\hline Сполука № 23 & 14,5 & $1,28 \pm 0,14^{\#}$ & 13,5 \\
\hline Сполука № 24 & 5,6 & $1,19 \pm 0,08^{\#}$ & 19,6 \\
\hline Сполука № 25 & 17,8 & $1,23 \pm 0,13^{\#}$ & 16,9 \\
\hline Контрольна патологія & - & $1,48 \pm 0,12^{\#}$ & - \\
\hline Сполука № 26 & 18,3 & $1,21 \pm 0,11$ \# & 5,5 \\
\hline Сполука № 27 & 43,3 & $1,25 \pm 0,09 \#$ & 2,3 \\
\hline Сполука № 28 & 37,3 & $1,14 \pm 0,04$ \# & 10,9 \\
\hline Сполука № 29 & 45,8 & $1,42 \pm 0,16$ \# & - \\
\hline Сполука № 30 & 50,3 & $1,48 \pm 0,19$ \# & - \\
\hline Контрольна патологія & - & $1,28 \pm 0,14$ \# & - \\
\hline Сполука № 31 & 23,4 & $1,24 \pm 0,18$ \# & 6,1 \\
\hline Сполука № 32 & 18,9 & $1,13 \pm 0,07$ \# & 14,4 \\
\hline Сполука № 33 & 13,3 & $1,09 \pm 0,04$ \# & 17,4 \\
\hline Сполука № 34 & 6,7 & $0,94 \pm 0,02$ *\# & 28,8 \\
\hline Сполука № 35 & 5,6 & $0,98 \pm 0,16^{\#}$ & 25,8 \\
\hline Контрольна патологія & - & $1,32 \pm 0,17^{\#}$ & - \\
\hline
\end{tabular}

ISSN 2312-0967. Pharmaceutical review. 2015. № 4 
Синтез біологічно активних сполук

Synthesis of biologically active compounds

Продовження табл. 2

\begin{tabular}{|l|c|c|c|}
\hline \multicolumn{1}{|c|}{1} & 2 & 3 & 4 \\
\hline Сполука № 36 & 4,4 & $1,31 \pm 0,13^{\#}$ & 12,8 \\
\hline Сполука № 37 & 24,8 & $1,22 \pm 0,21^{\#}$ & 18,0 \\
\hline Сполука № 38 & 34,0 & $1,14 \pm 0,09^{\#}$ & 21,6 \\
\hline Сполука № 39 & 11,8 & $1,09 \pm 0,04^{\#}$ & 8,6 \\
\hline Сполука № 40 & 77,8 & $1,27 \pm 0,13^{\#}$ & - \\
\hline Контрольна патологія & - & $1,39 \pm 0,19^{\#}$ & 6,0 \\
\hline Сполука № 41 & 13,0 & $1,41 \pm 0,16^{\#}$ & 9,3 \\
\hline Сполука № 42 & 6,3 & $1,36 \pm 0,12^{\#}$ & 14,0 \\
\hline Сполука № 43 & 6,5 & $1,29 \pm 0,07^{\#}$ & 54,7 \\
\hline Вольтарен & 8,0 & $0,68 \pm 0,11^{*}$ & - \\
\hline Контрольна патологія & - & $1,50 \pm 0,18^{\#}$ & \\
\hline
\end{tabular}

Примітки: * - статистично значущі відмінності з показниками групи контрольної патології, p<0,05;

\# - статистично значущі відмінності з показниками групи "Вольтарену", p<0,05.

Максимальна здатність впливати на процес гострого запалення на рівні препарату порівняння "Вольтарену" встановлена для сполуки № 16 (ди(2,4-диметил) анілід малонової кислоти).
На наступному етапі дослідження було вивчено анальгетичну активність нових сполук за умов «оцтовокислих судом» у щурів. Результати експерименту наведені у таблиці 3.

Таблиця 3. Анальгетична активність 43 похідних амідів малонової та щавлевої кислоти у щурів

\begin{tabular}{|c|c|c|c|}
\hline Група, шифр сполуки & Доза, мг/кг & Кількість судом, $(\mathrm{M} \pm \mathrm{m})$ & Анальгетична активність, \% \\
\hline 1 & 2 & 3 & 4 \\
\hline Сполука № 1 & 8,1 & $57,0 \pm 1,86^{\# \$}$ & 5,0 \\
\hline Сполука № 2 & 9,4 & $59,6 \pm 1,71^{\# \$}$ & 0,6 \\
\hline Сполука № 3 & 6,9 & $49,8 \pm 1,28 * \# \$$ & 17,0 \\
\hline Сполука № 4 & 10,6 & $47,6 \pm 2,21$ *\#\$ & 20,7 \\
\hline Сполука № 5 & 12,9 & $44,5 \pm 3,15$ *\#\$ & 25,8 \\
\hline Контрольна патологія & - & $60,0 \pm 1,52$ \#\$ & - \\
\hline Сполука № 6 & 15,6 & $58,4 \pm 1,72^{\text {\#\$ }}$ & 0,12 \\
\hline Сполука № 7 & 8,9 & $47,8 \pm 2,34$ *\#\$ & 28,1 \\
\hline Сполука № 8 & 18,1 & $41,9 \pm 1,92^{\star \# \$}$ & 40,0 \\
\hline Сполука № 9 & 21,3 & $49,5 \pm 2,32$ *\#\$ & 25,6 \\
\hline Сполука № 10 & 26,3 & $55,6 \pm 2,15$ *\#\$ & 16,4 \\
\hline Контрольна патологія & - & $66,5 \pm 1,67$ \#\$ & - \\
\hline Сполука № 11 & 26,8 & $65,2 \pm 2,54$ \#\$ & 6,2 \\
\hline Сполука № 12 & 81,2 & $68,0 \pm 1,94$ \#\$ & 2,2 \\
\hline Сполука № 13 & 66,3 & $70,5 \pm 2,79$ \#\$ & - \\
\hline Сполука № 14 & 16,3 & $62,0 \pm 1,93$ \#\$ & 10,8 \\
\hline Сполука № 15 & 15,8 & $58,6 \pm 1,69 * \# \$$ & 15,7 \\
\hline Контрольна патологія & - & 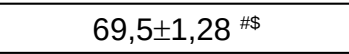 & - \\
\hline Сполука № 16 & 14,6 & $29,4 \pm 1,71^{*}$ & 58,9 \\
\hline Сполука № 17 & 16,8 & $81,0 \pm 1,93$ \#\$ & - \\
\hline Сполука № 18 & 20,0 & $78,0 \pm 3,29 \#$ & - \\
\hline Сполука № 19 & 17,0 & $69,5 \pm 3,21 \# \$$ & 2,8 \\
\hline
\end{tabular}

ISSN 2312-0967. Фармацевтичний часопис. 2015. № 4 
Синтез біологічно активних сполук Synthesis of biologically active compounds

Продовження табл. 3

\begin{tabular}{|c|c|c|c|}
\hline 1 & 2 & 3 & 4 \\
\hline Сполука № 20 & 17,3 & $66,4 \pm 2,97$ \#\$ & 7,1 \\
\hline Контрольна патологія & - & $71,5 \pm 1,15^{\# \$}$ & - \\
\hline Сполука № 21 & 13,3 & $59,4 \pm 2,366^{\# \$}$ & 6,5 \\
\hline Сполука № 22 & 14,8 & $57,1 \pm 3,00^{\# \$}$ & 10,0 \\
\hline Сполука № 23 & 14,5 & $55,2 \pm 2,15^{\star \# \$}$ & 13,1 \\
\hline Сполука № 24 & 5,6 & $50,4 \pm 1,94$ *\#\$ & 20,6 \\
\hline Сполука № 25 & 17,8 & $48,5 \pm 2,58$ *\#\$ & 23,6 \\
\hline Контрольна патологія & - & $63,5 \pm 1,08$ \#\$ & - \\
\hline Сполука № 26 & 18,3 & $70,2 \pm 1,50$ \#\$ & 5,9 \\
\hline Сполука № 27 & 43,3 & $69,5 \pm 1,84^{\# \$}$ & 6,8 \\
\hline Сполука № 28 & 37,3 & $62,8 \pm 1,92$ *\#\$ & 15,8 \\
\hline Сполука № 29 & 45,8 & $88,5 \pm 2,43^{\# \$}$ & - \\
\hline Сполука № 30 & 50,3 & $86,2 \pm 1,71^{\# \$}$ & - \\
\hline Контрольна патологія & - & $74,6 \pm 2,60$ \#\$ & - \\
\hline Сполука № 31 & 23,4 & $65,0 \pm 1,42 \#$ & 9,5 \\
\hline Сполука № 32 & 18,9 & $57,2 \pm 2,56$ *\#\$ & 20,3 \\
\hline Сполука № 33 & 13,3 & $51,9 \pm 2,16$ *\#\$ & 27,7 \\
\hline Сполука № 34 & 6,7 & $47,2 \pm 1,88$ *\#\$ & 34,3 \\
\hline Сполука № 35 & 5,6 & $48,4 \pm 2,36$ *\#\$ & 32,6 \\
\hline Контрольна патологія & - & $71,8 \pm 3,10^{\# \$}$ & - \\
\hline Сполука № 36 & 4,4 & $61,8 \pm 1,47^{\# \$}$ & 8,4 \\
\hline Сполука № 37 & 24,8 & $64,3 \pm 1,82^{\# \$}$ & 4,7 \\
\hline Сполука № 38 & 34,0 & $58,9 \pm 1,69$ \#\$ & 12,7 \\
\hline Сполука № 39 & 11,8 & $54,3 \pm 2,15$ *\#\$ & 19,6 \\
\hline Сполука № 40 & 77,8 & $57,9 \pm 2,74^{\# \$}$ & 14,2 \\
\hline Контрольна патологія & - & 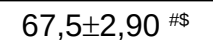 & - \\
\hline Сполука № 41 & 13,0 & $62,5 \pm 3,84^{\# \$}$ & 6,0 \\
\hline Сполука № 42 & 6,3 & $56,0 \pm 2,39 \#$ & 9,3 \\
\hline Сполука № 43 & 6,5 & $41,8 \pm 3,75$ * & 14,0 \\
\hline Вольтарен & 8,0 & $32,0 \pm 1,28$ * & 50,6 \\
\hline Анальгін & 50,0 & $34,5 \pm 2,36$ * & 46,8 \\
\hline Контрольна патологія & - & $1,50 \pm 0,18^{\#}$ & - \\
\hline
\end{tabular}

Примітки: * - статистично значущі відмінності з показниками групи контрольної патології, p<0,05;

\# - статистично значущі відмінності з показниками групи "Вольтарену", p<0,05;

\$ - статистично значущі відмінності з показниками групи анальгіну, p<0,05.

Експериментальна модель «оцтовокислих судом» дозволяє дослідити механізм периферичної анальгетичної дії нових субстанцій. В основі патогенезу цієї експериментальної моделі лежить хімічне больове подразнення.

Внутрішньоочеревинне введення розчину оцтової кислоти індукує загальну активацію ноцицептивної системи та сприяє місцевому вивільненню гістаміну, брадикініну, серотоніну, а також простагландинів та лейкотрієнів.

Вищезазначене призводить до розвитку мимовільних скорочень м'язів живота - «судом», що супроводжуються вигинанням спини та витягуванням твариною задніх кінцівок. У тварин груп контрольної патології кількість

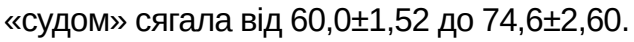

Не проявляли анальгезуючою дії сполуки під шифром № 6, 13, 17, 18, 29 та 30, які мали метоксильний, додецильний, метильний, циклогексильний та пропаноламідний радикал у основному ланцюзі молекули.

Слід зазначити, що з досліджуваних 43 сполук, 19 виявили потужну анальгетичну активність, про що свідчить статистично значуща різниця кількості «судом» від групи контрольної патології. Це сполуки під лабораторними шифррами: № 3, 4, 5, 7, 8, 9, 10, 15, 16,

ISSN 2312-0967. Pharmaceutical review. 2015. № 4 
Синтез біологічно активних сполук

Synthesis of biologically active compounds

23, 24, 25, 28, 32, 33, 34, 35, 39 та 43. Анальгетична активність зазначених сполук перебувала у діапазоні 13,1-58,9 \%. 3 них не мали вірогідних відмінностей від активності препаратів порівняння "Волтарену" та «Анальгіну» лише дві сполуки - № 16 та 43.

Аналіз отриманих результатів підтвердив, що сполука № 16 (ди-(2,4-диметил) анілід малонової кислоти) має тенденцію до перивищення ефективності рефреренс-препаратів, вольтарену на $8 \%$, анальгіну на $12 \%$.

Висновки. Отримані результати дослідження дозволили встановити закономірності протизапальної та анальгетичної активності від хімічної структури молекули для нових сполук та обрати для подальших фрармакологічних досліджень сполуку № 16, (ди-(2,4-диметил) анілід малонової кислоти) із максимальною протизапальною та анальгетичною дією.

\title{
Список літератури
}

1. Доклінічні дослідження лікарських засобів: метод. рек. / за ред. О. В. Стефранова. - К. : Авіцена, 2001. $528 \mathrm{c}$.

2. Программа статистического анализа. Режим электронного доступа www.analystsoft.com/ru

3. Рєзников О. Г. Загальні етичні принципи експериментів на тваринах / О. Г. Рєзников // Ендокринологія. - 2003. - T. 8, № 1. - C. 142-145.

4. Chaparro M. New molecules in the treatment of inflammatory bowel disease / M. Chaparro, J. P. Gisbert // Gastroenterol Hepatol. - 2015. - Vol. 26. - P. 210-215.

5. Metyrapone effect on gastroprotective action of

corticotropin-releasing factor administered centrally against indomethacin-induced gastric injury/ M. A. Miazina, T. R. Bagaeva, L. P. Filaretova // Ross Fiziol. Zh. Im. I. M. Sechenova. - 2014. - №100(12). - P. 1421-1430.

6. Mkontwana N. Oral analgesia for relieving postcaesarean pain/ N. Mkontwana, N. Novikova // Cochrane Database Syst Rev. -2015. - Vol. 29(3) . - P. 450-456.

7. Seyed Mirzaei S.M. Non-Steroidal AntiInflammatory Drug Related Peptic Ulcer Disease in Patients Referred to Afzalipour Hospital / S. M. Seyed Mirzaei, M. J. Zahedi, S. Shafiei Pour // Middle East J. Dig Dis. 2015. - Vol.7(4). - P. 241-244.

\section{ИЗУЧЕНИЕ ЗАВИСИМОСТИ СВЯЗЕЙ «СТРУКТУРА - ПРОТИВОВОСПАЛИТЕЛЬНОЕ ДЕЙСТВИЕ» И «СТРУКТУРА - АНАЛЬГЕТИЧЕСКОЕ ДЕЙСТВИЕ» СРЕДИ ПРОИЗВОДНЫХ АМИДОВ МАЛОНОВОЙ И ЩАВЕЛЕВОЙ КИСЛОТ}

\author{
Н. Г. Вахнина \\ Национальный фрармацевтический университет, Харьков
}

\begin{abstract}
Резюме: статья посвящена исследованию противовоспалительного и анальгетического действия 43 новых производных малоновой и щавелевой кислот и изучению зависимости связи «структура - фрармакологическая активность».

Скрининговые исследования были проведены на моделях острого каррагенинового отека и «уксуснокислых судорог» у крыс. Для новых соединений установлены закономерности антиэксудативной и противоболевой активности от химической структуры молекулы. Установлено, что из 43 изучаемыхсоединений максимальноепротивовоспалительноеианальгетическое действие проявляет соединение под лабораторным шифром 16 (ди-(2,4-диметил)-анилид малоновой кислоты).
\end{abstract}

Ключевые слова: производные малоновой кислоты, производные щавелевой кислоты, противовоспалительное действие, анальгетическое действие.

\section{RESEARCH OF RELATIONSHIP «STRUCTURE - ANTI-INFLAMMATORY EFFECT» AND «STRUCTURE - ANALGESIC EFFECT» AMONG AMIDE DERIVATIVES OF MALONIC AND OXALIC ACIDS}

\section{N. H. Vakhnina}

National University of Pharmacy

Summary: in the paper, we consider the anti-inflammatory and analgesic effect of 43 new malonic and oxalic acids derivatives and research of «structure - pharmacological activity» relationship.

Screening studies were conducted on rats for models of acute carrageenan edema and «acetic acid writhing». For new compounds a relation was established between antiexudative and analgesic activities and of the chemical structure of molecules.

The compound with laboratory code 16 (di- (2,4-dimethyl) malonic acid anilide) was found to show maximal anti-inflammatory and analgesic effect among 43 studied compounds.

Key words: malonic acid, oxalic acid, anti-inflammatory action, analgesic action.

ISSN 2312-0967. Фармацевтичний часопис. 2015. № 4 